\title{
Range Site and Grazing System Influence Regrowth after Spraying Honey Mesquite
}

\section{J. SCIFRES, M. M. KOTHMANN, AND G. W. MATHIS}

Highlight: Honey mesquite (Prosopis glandulosa Torr. var. glandulosa) regrowth on the Texas Experimental Ranch in the Rolling Plains of northwest Texas was evaluated 8 years after aerial spraying with 2,4,5-T. Regrowth on rocky hill, rolling hill, and deep upland range sites was measured under two systems of grazing management: heavily stocked (4.86 ha/AU), continuous grazing; and, moderately stocked (6.48 ha/AU), deferred-rotation grazing. Canopy cover, density, and topgrowth production of honey mesquite regrowth were significantly greater under moderate, deferred-rotation grazing than under heavy, continuous grazing of the deep upland site. Honey mesquite density, canopy cover, and topgrowth production did not differ between grazing systems on the rocky hill site. Regrowth on the rolling hill site was usually intermediate between the rocky hill and deep upland sites. Honey mesquite plant density, topgrowth production, canopy cover, and rate of new stem initiation were greater under moderately stocked, deferred-rotation than heavily stocked, continuous grazing. Averaged across grazing systems, regrowth, regardless of variable evaluated, was greatest on the deep upland site.

The Rolling Plains of Texas occupies some 10 million ha of gently rolling to moderately rough topography in semiarid, northwest Texas (Gould, 1969). About two-thirds of the area is rangeland supporting cow-calf operations. Honey mesquite (Prosopis glandulosa Torr. var. glandulosa $)^{1}$ is the most troublesome woody invader of these rangelands.

Standard spraying treatment for honey mesquite control in the Rolling Plains is $0.56 \mathrm{~kg} / \mathrm{ha}$ of $2,4,5$-trichlorophenoxyacetic acid $(2,4,5-\mathrm{T})$ in 15 to 20 liters/ha of a $1: 4$ or $1: 3$ diesel oil:water emulsion. Usually, only 20 to $25 \%$ of the honey mesquite plants in the treated population are "root-killed" by such applications (Fisher et al., 1972). The remainder of the population, with the tops killed by spraying, develop new aerial growth by sprouting from the stem base or the "crown" (Young et al., 1948). The

\footnotetext{
The authors are associate professors, Department of Range Sciences, Texas A\&M University, College Station; and research associate, Texas Experimental Ranch, Throckmorton.

Approved for publication by the Director, Texas Agr. Exp. Sta., as Tech. Article 10502.

Authors acknowledge support of the Texas Experimental Ranch Committee and Swenson Land \& Cattle Co., Inc., who, in cooperation with the Texas Agr. Exp. Sta., make studies such as the present one possible. Mr. Mathis is now ranch manager, Swenson Land \& Cattle Co., Stamford, Texas.

Manuscript received J une 4, 1973.
}

${ }^{1}$ Scientific names follow Gould, F. W. (1969). "crown" is now recognized as a compressed section of stem, and evidently the result of a morphological or genetic adaptation to environmental conditions. When released from apical dominance, buds along live stem segments, aerial or buried, readily produce new stems and leaves (Meyer et al., 1971). Prolific sprouting gives rise to a many-stemmed, shrubbytype growth that often presents more difficult range management problems than the original, single-stemmed, treetype infestations of honey mesquite.

It is commonly thought that a "good grass cover," maintained through proper management of grazing animals, retards development of honey mesquite (Fisher et al., 1959). This has been substantiated relative to seedlings invading rangeland (Scifres et al., 1971). However, there are no quantitative data which describe the influence of range site or grazing management factors on regrowth potential or regrowth development following efforts to control established honey mesquite. The Texas Experimental Ranch near Throckmorton provided an opportunity to evaluate honey mesquite regrowth as influenced by range site and grazing management, following aerial spraying with $2,4,5-\mathrm{T}$ at $0.56 \mathrm{~kg} / \mathrm{ha}$.

\section{Grazing Management Systems}

Two grazing management systems, each comprising about 450 ha, were included in the study. Both were grazed in a cow-calf operation, one yearlong at the rate of $4.86 \mathrm{ha} / \mathrm{AU}$, heavy continuous grazing (HCG), and the other under a 4-pasture, deferred-rotation system stocked at $6.48 \mathrm{ha} / \mathrm{AU}$, moderate deferred-rotation grazing (MDG). The 4-pasture system was grazed with three herds of livestock. One herd was rotated at each 4-month interval to give each pasture 12 months grazing followed by 4 months rest.

\section{Description of Study Site}

Three range sites (deep upland, rolling hill, and rocky hill) were studied within each grazing system. The Abilene, Crawford, Rowena and Tobosa soil series comprise the deep upland site. This is the predominant range site on the Experimental Ranch and accounts for $41 \%$ of the total study area. Characteristically, these are dark clays and clay loams, moderate to slowly permeable and well drained. Depth of top soil above parent material ranges from about 50 to $200 \mathrm{~cm}$ and slope varies from 0 to $3 \%$. Soils in these series are generally highly fertile and have high available water-holding capacities. They differ mainly in distribution of calcareous material in the soil horizons.

Texas wintergrass (Stipa leucotricha Trin. A Rupr.) and buffalograss (Buchloe dactyloides (Nutt.) Engelm.) are the principal grasses on the deep upland site, with sideoats grama (Bouteloua curtipendula (Michx.) Torr.) as the next most abundant species (Table 1). Species composition of vegetation on this site has changed in response to different grazing treatments (Mathis and Kothmann, 1968). Under heavy, yearlong stocking, buffalograss is the dominant species with Texas wintergrass declining and sideoats grama remaining relatively stable as a minor species. On all moderately stocked pastures, Texas wintergrass is the dominant species associated with a significant decline in buffalograss. Honey mesquite and plains pricklypear (Opuntia polyacantha Haw.) are the primary undesirable species on the deep upland site.

The rolling hill site, comprising $34 \%$ of the experimental area, includes the Metera and Throck soil series. Surface 
Table 1. Species composition (\%) by weight and available forage $(\mathrm{kg} / \mathrm{ha})$ in 1972 on three range sites under two grazing systems, which were used for study of honey mesquite regrowth in the Rolling Plains near Throckmorton, Tex.

\begin{tabular}{|c|c|c|c|c|c|c|}
\hline \multirow[b]{2}{*}{ Species } & \multicolumn{2}{|c|}{ Deep upland } & \multicolumn{2}{|c|}{ Rolling hill } & \multicolumn{2}{|c|}{ Rocky hill } \\
\hline & $\begin{array}{c}\text { Heavily } \\
\text { stocked, } \\
\text { continuous }\end{array}$ & $\begin{array}{l}\text { Moderately } \\
\text { stocked, } \\
\text { deferred- } \\
\text { rotation }\end{array}$ & $\begin{array}{c}\text { Heavily } \\
\text { stocked, } \\
\text { continuous }\end{array}$ & $\begin{array}{l}\text { Moderately } \\
\text { stocked, } \\
\text { deferred- } \\
\text { rotation }\end{array}$ & $\begin{array}{c}\text { Heavily } \\
\text { stocked, } \\
\text { continuous }\end{array}$ & $\begin{array}{c}\text { Moderately } \\
\text { stocked, } \\
\text { deferred- } \\
\text { rotation }\end{array}$ \\
\hline Buffalograss & 47 & 15 & 28 & 20 & 24 & 14 \\
\hline Texas wintergrass & 31 & 52 & 25 & 22 & 6 & 11 \\
\hline Sideoats grama & 5 & 11 & 7 & 31 & 26 & 18 \\
\hline Threeawn & 4 & 3 & 18 & 9 & 14 & 12 \\
\hline Misc. grasses & 6 & 9 & 13 & 12 & 19 & 34 \\
\hline Forbs & 8 & 10 & 10 & 7 & 11 & 12 \\
\hline Available forage & 1103 & 1617 & 1046 & 1475 & 728 & 1146 \\
\hline
\end{tabular}

soils of these series are dark, greyish brown, silty clay loams ranging in depth from 38 to $50 \mathrm{~cm}$ with slopes of 1 to $5 \%$. I'hey are highly calcarcous, and outcroppings of flat limestone occur frequently on the surface. These soils are moderately permeable and highly fertile, but water storage is restricted because of their shallow depth. Texas wintergrass, the dominant species on the rolling hill site, grows primarily on the deeper soils. Sideoats grama is the second most important species. Buffalograss and threeawns (Aristida sp.) are the other important forage species. Species composition changes are more rapid than on the deep upland site (Mathis and Kothmann, 1968). Under moderate stocking, sideoats grama and Texas wintergrass increase on this site. Deferred-rotation grazing has been effective in increasing the rate of change. Honey mesquite and lotebush (Condalia obtusifolia (Ilook.) Weberb.) are the primary brush species on the rolling hill site.

Soils of the Owens-Tarrant complex constitute the rocky hill site. These are shallow, stony clays characterized by limestone rocks on the surface that vary in size from small cobbles to large boulders. Soil depth above parent material ranges from 13 to $50 \mathrm{~cm}$. Fertility level is generally high but permeability is moderate to very slow. This range site occurs on steep slopes and rocky ridges where surface runoff is rapid. About $17 \%$ of the Experimental Ranch is contained in this site. Sideoats grama is the major species of the rocky hill site with threeawns, buffalograss, and Texas wintergrass the more important secondary species. This sitc generally responds quickly to improved grazing management. If properly grazed, the site has good production potential.

\section{Evaluation Methods}

Honey mesquite regrowth was evaluated on each range site in two pastures under both grazing management systems. The point-centered quarter (Cottam and Curtis, 1956) was used as the basic evaluation method. Four lines, $410 \mathrm{~m}$ long and about $100 \mathrm{~m}$ apart, were established on each site. Twenty-five, equallyspaced points were established along each line. The distance from the central point to the center of nearest honey mesquite plant in each quadrant was recorded. Data recorded for each regrowth plant included the height, canopy width and number of stems. On the first 10 points of each line, the basal diameter of each primary honey mesquite stem was recorded. Although it is realized that several branches may arise from a single branch beneath the soil line, primary stems are defined as those originating below ground line (Scifres et al., 1971). Twenty plants measured in the above manner were harvested from each site, separated into foliage and stems, and weighed. Subsamples were taken from each harvested plant for moisture determinations and all plant weights were converted to an oven-dry basis.

Canopy volumes were estimated using the formula $0.167 \pi \mathrm{h}\left(\mathrm{h}^{2}+3 \mathrm{r}^{2}\right)$ where $h$ $=$ plant height to the tallest extended primary stem and $r=$ canopy radius at the widest point. A regression equation was developed for canopy volume and honey mesquite production values as suggested by Cook (1960). The equation, $\mathrm{Y}=$ $126.87+370(\mathrm{X})$ where $Y=$ oven-dry honey mesquite production/plant (g) and $X=$ canopy volume/plant $\left(\mathrm{m}^{3}\right)$, was utilevaluated along the original lines. The two plant attributes were highly correlated $(r=0.98)$. Average plant production and density values were used to estimate production per unit area $(\mathrm{kg} / \mathrm{ha})$ of aerial honey mesquite regrowth.

About 800 basal stem samples were collected to investigate the relationship between stem age and radial growth. This method was essentially the same as described by Scifres et al. (1971) in similar studies with honey mesquite. Linear, quadratic, and cubic regression equations were developed for each site and grazing system using stem diameter as the independent variable and number of growth ized to estimate production of all plants rings as the dependent variable. The best predictive equation for each site was then utilized in estimating stem age to compensate for inherent variation in growth rate.

\section{Results and Discussion}

Regrowth Density, Canopy Cover and Topgrowth Production

On the rocky hill site, grazing management did not significantly influence regrowth plant density (Table 2). However, on the deep upland and rolling hill sites, regrowth densities were greater under MDG than under HCG. Plant densities for honey mesquite regrowth ranked by sites were: deep upland $\geqslant$ rolling hill $>$ rocky hill. Honey mesquite densities by grazing system averaged across sites were higher under MDG than under HCG.

Table 2. Density of live honey mesquite (plants/ha) on three range sites under two grazing systems in May, 1972 after aerial spraying in the Rolling Plains near Throckmorton, Tex., in June, 1964. ${ }^{1}$

\begin{tabular}{|c|c|c|c|}
\hline \multirow[b]{2}{*}{ Range site } & \multicolumn{2}{|c|}{ Grazing system } & \multirow[b]{2}{*}{$\begin{array}{l}\text { Site } \\
\text { avg }\end{array}$} \\
\hline & $\begin{array}{l}\text { Heavily } \\
\text { stocked, } \\
\text { continuous }\end{array}$ & $\begin{array}{l}\text { Moderately } \\
\text { stocked, } \\
\text { deferred- } \\
\text { rotation }\end{array}$ & \\
\hline $\begin{array}{l}\text { Deep upland } \\
\text { Rolling hill } \\
\text { Rocky hill }\end{array}$ & $\begin{array}{l}111 \mathrm{a} \\
170 \mathrm{~b} \\
177 \mathrm{~b}\end{array}$ & $\begin{array}{l}356 \mathrm{a} \\
248 \mathrm{c} \\
164 \mathrm{~b}\end{array}$ & $\begin{array}{l}234 \mathrm{~s} \\
209 \mathrm{st} \\
171 \mathrm{t}\end{array}$ \\
\hline $\begin{array}{l}\text { Grazing syste } \\
\text { avg }\end{array}$ & $153 \mathrm{q}$ & $256 \mathrm{r}$ & 205 \\
\hline
\end{tabular}

Canopy cover followed the same general trends as did plant density (Table 3). However, canopy cover was not significantly different among sites under HCG. There was no difference between rolling hill and rocky hill sites relative to honey mesquite regrowth canopy cover regardless of grazing system. Both the lowest

Table 3. Canopy cover (\%) of honey mesquite regrowth on three range sites and under two grazing systems in May, 1972, after aerial spraying in the Rolling Plains near Throckmorton, Tex., in June, $1964 .^{1}$

\begin{tabular}{|c|c|c|c|}
\hline \multirow[b]{2}{*}{ Range site } & \multicolumn{2}{|c|}{ Grazing system } & \multirow[b]{2}{*}{$\begin{array}{l}\text { Site } \\
\text { avg }\end{array}$} \\
\hline & $\begin{array}{c}\text { Heavily } \\
\text { stocked, } \\
\text { continuous }\end{array}$ & $\begin{array}{l}\text { Moderately } \\
\text { stocked, } \\
\text { deferred- } \\
\text { rotation }\end{array}$ & \\
\hline $\begin{array}{l}\text { Deep upland } \\
\text { Rolling hill } \\
\text { Rocky hill }\end{array}$ & $\begin{array}{l}1.6 \mathrm{a} \\
2.8 \mathrm{ab} \\
2.2 \mathrm{ab}\end{array}$ & $\begin{array}{l}8.0 \mathrm{c} \\
3.5 \mathrm{~b} \\
2.8 \mathrm{ab}\end{array}$ & $\begin{array}{l}4.8 \mathrm{v} \\
3.2 \mathrm{vw} \\
2.5 \mathrm{w}\end{array}$ \\
\hline $\begin{array}{l}\text { Grazing syster } \\
\text { avg }\end{array}$ & $2.2 \mathrm{x}$ & $4.8 \mathrm{y}$ & 3.5 \\
\hline
\end{tabular}

${ }^{1}$ Means followed by the same letter are not significantly different at the $5 \%$ level. 
(HCG) and the highest (MDG) canopy covers occurred on the deep upland site. Sites under HCG had lower canopy cover of honey mesquite regrowth than those under MDG.

Production of honey mesquite topgrowth did not differ among range sites under HCG (Table 4). Under MDG, honey mesquite regrowth production was greatest on deep upland and least on rocky hill. Production of honey mesquite regrowth under HCG was about a third of that from MDG.

\section{Regrowth Stem Development}

Density of stems originating in 1963 or earlier was used as an index of survival of the spray operation. Stem density cannot be related to plant density since original stems/plant are not known. Stems surviving the 1964 spray treatment were 66/ha (HCG) and 56/ha (MDG) for rocky hill; 189/ha (HCG) and 427/ha (MDG) for rolling hill; and, 13/ha (HCG) and $85 /$ ha (MDG) for deep upland.

The greatest difference in rate of stem initiation between grazing systems occurred on the deep upland site (Fig. 1). Under MDG an average of about 300 new stems were initiated/ha/year. Under HCG about 15 new stems/ha were initiated in 1964 , followed by a steady increase to 125 stems/ha in 1971. During 1971 and 1972, there was little difference between grazing systems on the deep upland site relative to new stem initiation. Total numbers of stems initiated during the 8-year period were 666 (HCG) and 2848 (MDG). These were about 50- and 35-fold increases over the stem densities that survived the spraying.

For the first 4 years after spraying, an average of about 75 more primary stems/ ha/year were initiated under MDG than under HCG on the rolling hill site (Fig. 1). There was no apparent difference

Table 4. Oven-dry production $(\mathrm{kg} / \mathrm{ha})$ of honey mesquite acrial, plant parts on three range sites under two grazing systems in May, 1972, af ter aerial spraying in the Rolling Plains near Throckmorton, Tex., in June, $1964 .^{1}$

\begin{tabular}{lcrc}
\hline \hline & \multicolumn{2}{c}{ Grazing system } & \\
\cline { 2 - 3 } & $\begin{array}{c}\text { Heavily } \\
\text { stocked, } \\
\text { continuous }\end{array}$ & $\begin{array}{c}\text { Moderately } \\
\text { stocked, } \\
\text { deferred- } \\
\text { rotation }\end{array}$ & $\begin{array}{l}\text { Site } \\
\text { avg }\end{array}$ \\
\hline Range site & 123 a & $1,013 \mathrm{c}$ & $568 \mathrm{u}$ \\
Deep upland & $269 \mathrm{a}$ & $622 \mathrm{~b}$ & $446 \mathrm{v}$ \\
Rolling hill & $192 \mathrm{a}$ & $233 \mathrm{a}$ & $213 \mathrm{w}$ \\
Rocky hill & $195 \mathrm{x}$ & $623 \mathrm{y}$ & 409 \\
Grazing system & & & \\
\multicolumn{1}{c}{ avg } & 195 &
\end{tabular}

${ }^{1}$ Means followed by the same letter are not significantly different at the $5 \%$ level.

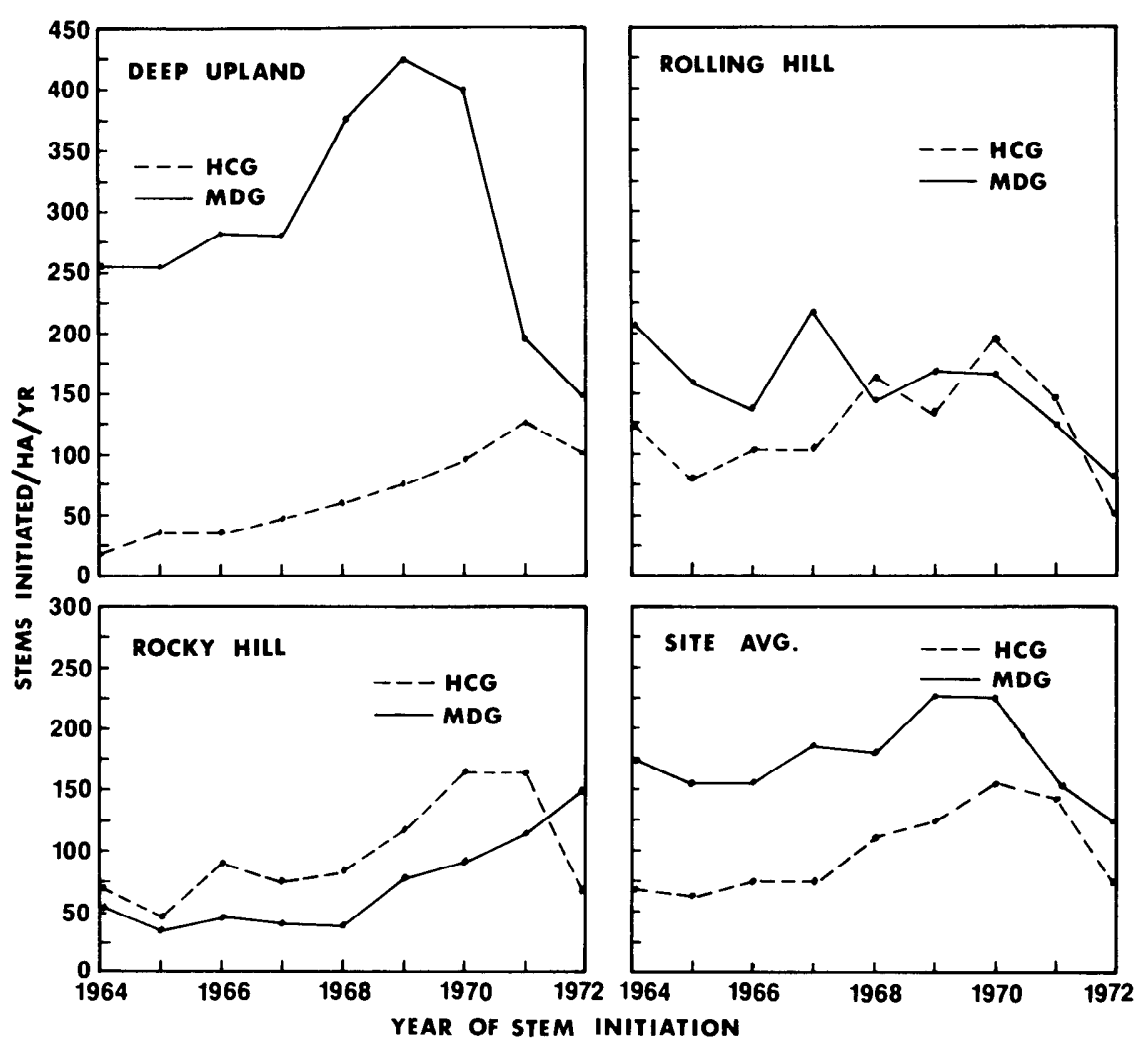

Fig. 1. Honey mesquite regrowth stems initiated annually following application of 2,4,5-T at 0.56 $\mathrm{kg} / \mathrm{ha}$ in spring, 1964, to three range sites under two grazing management systems on the Texas Experimental Ranch near Throckmorton.

between grazing systems in primary stem initiation on the rolling hill site from 1968 to 1971. Rate of increase in new stem initiation was less on rolling hill than on the other two range sites. Stcm densities increased 4- and 7-fold during the eight seasons following spraying under MDG and HCG, respectively. Average numbers of new stems initiated/ha/ year were 119 (HCG) and 159 (MDG), with cumulative totals of 1258 and 1860 new stems/ha.

No obvious difference in rate of initiation of primary stems following herbicide application was apparent between grazing systems on the rocky hill site (Fig. 1). In contrast to the other sites, there was a trend for greater initiation of new stems under HCG than under MDG. Average rates of stem initiation were 103 and 72 stems/ha/year for HCG and MDG pastures, respectively.

Averaged across sites, there were more primary stems initiated/ha/year under MDG than under HCG (Fig. 1). Associated with the general decline in stem initiation in 1971 and 1972 was a period of below normal rainfall from summer of 1970 until summer, 1971. Yearly differences in stem initiation, however, were not correlated with total annual precipitation $(r=0.14)$.
There were few significant differences among sites within grazing systems as to number of primary stems per regrowth plant (Table 5). Under MDG there were significantly more primary stems on regrowth plants on the deep upland site than on the rocky hill site. When averaged across grazing systems, there were fewer primary stems/regrowth plant on rocky hill than on the other range sites.

Although there were no significant differences in height of primary stems of regrowth honey mesquite among range sites within grazing systems studied, there was a trend toward shorter stems on regrowth on rocky hill sites (Table 5). Grazing systems, averaged across sites, had no significant influence on height of regrowth stems.

Response of honey mesquite regrowth to range site and grazing system influences should not be confused with environmental pressures on seedling establishment. The requisites for ecesis, primarily opening of rangeland communities, adequate moisture, and optimum temperature for seed germination and seedling growth of honcy mesquite, have been documented (Fisher et al., 1959; Scifres et al., 1971; Scifres and Brock, 1972). Regrowth honey mesquite consists of 
Table 5. Primary stems/plant and average height $(\mathrm{m})$ of honey mesquite regrowth plants on three range sites under two grazing systems in May, 1972, after aerial spraying in the Rolling Plains near Throckmorton, Tex., in June, 1964. ${ }^{1}$

\begin{tabular}{|c|c|c|c|}
\hline \multirow[b]{2}{*}{$\begin{array}{c}\text { Measurement } \\
\text { and } \\
\text { range site }\end{array}$} & \multicolumn{2}{|c|}{ Grazing system } & \multirow[b]{2}{*}{$\begin{array}{l}\text { Site } \\
\text { avg }\end{array}$} \\
\hline & $\begin{array}{c}\text { Heavily } \\
\text { stocked, } \\
\text { continuous }\end{array}$ & $\begin{array}{l}\text { Moderately } \\
\text { stocked, } \\
\text { deferred- } \\
\text { rotation }\end{array}$ & \\
\hline \multicolumn{4}{|c|}{ Primary stems/plant } \\
\hline Deep upland & $6.0 \mathrm{ab}$ & $8.0 \mathrm{~b}$ & $7.0 \mathrm{y}$ \\
\hline Rolling hill & $7.4 \mathrm{ab}$ & $7.5 \mathrm{ab}$ & $7.5 \mathrm{y}$ \\
\hline Rocky hill & $5.3 \mathrm{ab}$ & $4.3 \mathrm{a}$ & $4.8 \mathrm{z}$ \\
\hline $\begin{array}{l}\text { Grazing } \\
\text { system avg }\end{array}$ & $6.2 \times$ & $6.6 \mathrm{x}$ & \\
\hline \multicolumn{4}{|l|}{ Height/plant } \\
\hline Deep upland & $1.30 \mathrm{c}$ & $1.62 \mathrm{c}$ & $1.46 \mathrm{r}$ \\
\hline Rolling hill & $1.12 \mathrm{c}$ & $1.54 \mathrm{c}$ & $1.33 \mathrm{qr}$ \\
\hline Rocky hill & $1.09 \mathrm{c}$ & $1.28 \mathrm{c}$ & $1.19 \mathrm{q}$ \\
\hline $\begin{array}{l}\text { Grazing } \\
\text { system avg }\end{array}$ & $1.17 \mathrm{~s}$ & $1.48 \mathrm{~s}$ & \\
\hline
\end{tabular}

${ }^{1}$ Means followed by the same letter are not significantly different at the $5 \%$ level.

new stems that arise from the crowns of plants with established root systems.

In this study, regardless of range site, extent of regrowth was reduced on heavily stocked, continuously grazed pastures when compared to moderately stocked, deferred-rotationally grazed pastures. Although occasionally utilized during certain growing seasons, browsing of honey mesquite by livestock is probably not responsible for this difference. ${ }^{2}$

The increased regrowth of honey mesquite under MDG probably can be attributed to changes in site conditions that werc generally more favorable to plant growth. More research is needed in this area to clearly understand such vegetation-management-site influences.

\section{Literature Cited}

Cook, C. W. 1960. The use of multiple regression and correlation in biological investigations. Ecology 41:556-560.

Cottam, G., and J. T. Curtis. 1956. The use of distance measures in phytosociological sampling. Ecology 37:451-460.

Fisher, C. E., C. H. Meadors, R. Behrens, E. D. Robison, P. T. Marion and H. L. Morton. 1959. Control of mesquite on grazing lands. Texas Agr. Exp. Sta. Bull. 935. 24 p.

${ }^{2}$ Taylor, Charles A. 1973. Botanical composition of cattle diets on a 7-past ure, high-intensity, low-frequency grazing system. MS thesis. Dep. Range Sci., Texas A\&M Univ., College Station,
Fisher, C. E., J. L. Fults, and H. Hopp. 1949. Factors affecting action of oils and water soluble chemicals in mesquite eradication. Ecol. Monog. 16:109-126.

Fisher, C. E., H. T. Wiedemann, J. P. Walter, C. H. Meadors, J. H. Brock, and B. T. Cross. 1972. Brush control research on rangeland. Texas Agr. Exp. Sta. MP-1043. 18 p.

Gould, F. W. 1969. Texas plants: a checklist and ecological summary. Texas Agr. Exp. Sta. MP-585. $112 \mathrm{p}$.

Mathis, G. W., and M. M. Kothmann. 1968. Forage response to grazing treatments. Dep. Tech. Rep. No. 7, Texas Agr. Res. Sta., Spur, Tex.

Meyer, R. E., H. L. Morton, R. H. Haas, and E. D. Robison. 1971. Morphology and anatomy of honey mesquite. U. S. Dep. Agr. Tech. Bull. 1423. 186 p.

Scifres, C. J., and J. H. Brock. 1972. Emergence of honey mesquite seedlings relative to planting depth and soil temperature. J. Range Manage. 25:217-219.

Scifres, C. J., J. H. Brock, and R. R. Hahn. Influence of secondary succession on honey mesquite invasion in North Texas. J. Range Manage. 24:206-210.

Scifres, C. J., and R. R. Hahn. 1971. Response of honey mesquite seedlings to top removal. J. Range Manage. 24:296-298.

Young, V. A., F. R. Anderwald, and W. G. McCully. 1948. Brush problems on Texas ranges. Texas Agr. Exp. Sta. Misc. Publ. 21. $19 \mathrm{p}$.

\section{回可}
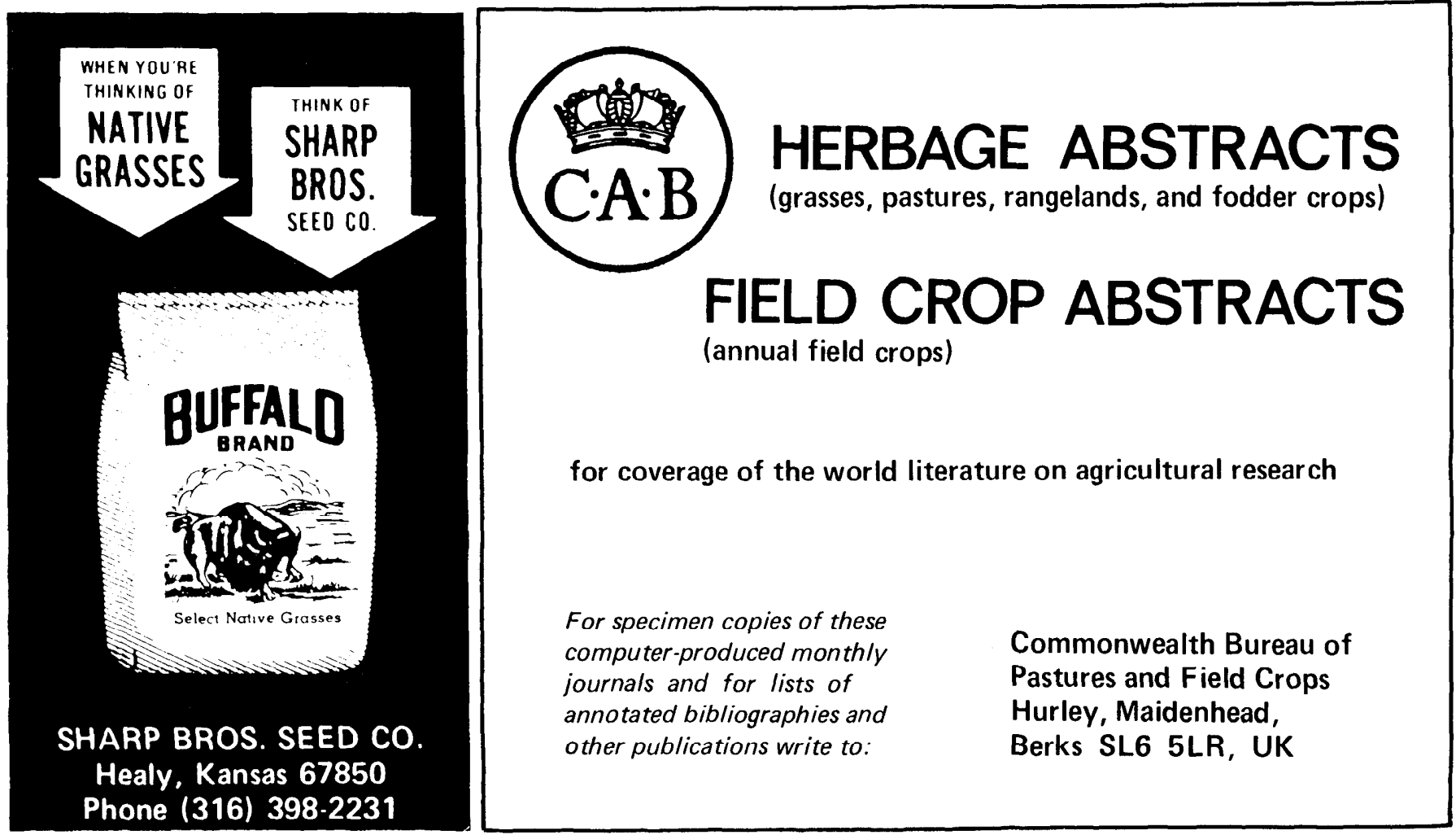